\title{
Hair diseases: a big problem on a small surface
}

\author{
Ligia A. Brzezińska-Wcisło', Dominika Wcisło-Dziadecka²
}

1Department of Dermatology, School of Medicine in Katowice, Medical University of Silesia, Katowice, Poland 2Department of Skin Structural Studies, Chair of Cosmetology, School of Pharmacy with Division of Medicine in Sosnowiec, Medical University of Silesia, Katowice, Poland

Adv Dermatol Allergol 2016; XXXIII (5): 317-322

DOI: $10.5114 / a d a .2016 .62834$

\begin{abstract}
Civilizational progress initially contributes to the problem of hair loss and then to alopecia as regards both frequency and therapeutic dilemmas. The work presents trichological problems which occur more rarely, i.e. drug-induced, anagen and telogen alopecia, congenital and acquired structural hair disorders, psychic disturbances concerning the hair as well as the hair during menopause. Then, the article briefly describes contagious (infectious) diseases as well as diseases with inflammatory etiology which are accompanied by exfoliation and (frequently) pruritus. Finally, alopecia cicatricans is discussed. Alopecia areata and androgenetic alopecia are omitted herein because they occur more often and will be described in another work. Any disproportions and upset balance concerning correct functioning of mechanisms within the scalp hair system are the evidence of pathologies.
\end{abstract}

Key words: hair disease, pathogenesis, treatment.

\section{Introduction}

Civilizational progress initially contributes to the problem of hair loss and then to alopecia as regards both frequency and therapeutic dilemmas [1].

The work presents trichological problems which occur more rarely, i.e. drug-induced, anagen and telogen alopecia, congenital and acquired structural hair disorders, psychic disturbances concerning the hair. Then, the article briefly describes contagious (infectious) diseases as well as diseases with inflammatory etiology which are accompanied by exfoliation and (frequently) pruritus. Finally, alopecia cicatricans is discussed. Alopecia areata and androgenetic alopecia are omitted herein because they occur more often and will be described in another work. Any disproportions and upset balance concerning correct functioning of mechanisms within the scalp hair system are the evidence of pathologies.

Drug-induced hair loss is nearly always reversible. It is caused by toxic action exerted by the drug on the hair follicle matrix cells because the toxic factor affects only anagen hairs. The alopecia mechanism is usually a telogen one and depends on the drug type and dose, the entire therapeutic scheme and the patient's individual sensitivity. Clinical symptoms of alopecia caused by cytostatic drugs include diffuse hair thinning of various intensity, (sometimes) nearly complete alopecia and head top alopecia which does not affect the peripheral areas. They can also cause structural changes of the hair shaft such as the Pohl-Pinkus symptom (segmental hair shaft constriction). Hairs on other parts of the body have a long telogen phase and are thus less vulnerable to the action of cytostatic drugs. Moreover, the length of anagen and telogen beyond the scalp is also different. Patients with gray or red hair may see that the hair that grows again is dark, while those with straight hair - that it grows again as curly [2-5].

Twenty-thirty percent of patients treated with orally administered retinoids develop alopecia and it may concern body hairs, too, but it grows again 3 months after the end of the therapy $[1,3,6]$. Fifty percent of patients receiving antithrombotic drugs suffer from hair loss and the trichological examination reveals a telogen alopecia pathomechanism [1, 3].

Anticoagulants are another cause of hair thinning, which usually occurs between the third and the $20^{\text {th }}$ week after the beginning of the therapy $[1,3,7]$.

Address for correspondence: Prof. Ligia A. Brzezińska-Wcisło MD, PhD, Department of Dermatology, Medical University of Silesia, 20/24 Francuska St, 40-027 Katowice, Poland, phone: +48 3225611 82, fax: +48 3225611 82, e-mail: kikderm@sum.edu.pl Received: 3.03.2016, accepted: 9.03.2016. 
Drugs used in rheumatology such as gold salts, methotrexate or sulfasalazine may also contribute to hair thinning and thus lead to alopecia [1, 3].

Many drugs used in psychiatry and neurology cause alopecia or significant hair thinning (in approx. 20\% of patients) $[1,3,8]$.

Considering cardiological drugs, drug-induced alopecia affecting the whole body may be caused by statins and fibrates $[1,3,9]$ as well as angiotensin-converting enzyme (ACE) inhibitors, $\beta$-adrenolytic drugs and calcium channel blockers. Synthetic thyroid gland hormones used in therapies are also responsible for developing the telogen alopecia mechanism [3, 10].

Oral contraceptives may cause an increased hair loss or even lead to alopecia (this concerns approx. 9\% of women) [3].

Drug-induced structural changes of hair shaft include shaft straightening, which is reported after using lithium or interferon, whereas shaft twisting may occur after using chemotherapeutics, retinoids or the valproic acid.

Chloroquine may cause temporal and eyebrow hair discolorations in light-haired and red patients 3 months after beginning the therapy $[3,11]$.

\section{Anagen alopecia}

Anagen alopecia is found first and foremost on the scalp because this area has the greatest number of hairs in the anagen phase. It does not occur in other areas because the hair cycles are very short and another cycle starts before a toxic factor begins to exert its action. Hair loss is very fast. The treatment consists in stopping the provoking factor so that hair follicles retain their ability to form new hairs. This alopecia is caused by certain drugs (mainly chemotherapeutics) as well as poisoning by heavy metals, plants (mainly tropical ones) and animal toxins $[2,12,13]$.

\section{Telogen alopecia}

This alopecia may be caused by diseases involving high fever, a shock to the body stemming from a serious surgical procedure, stress, certain drugs, diabetes, hormonal disorders and (in women) other factors such as labor, coming off hormonal contraceptives containing large estrogen doses or sudden dietetic limitations. It is usually generalized and hair loss is influenced by individual sensitivity as well as the period and intensity of the action exerted by the detrimental factor. The term 'chronic telogen alopecia' refers to a generalized chronic hair loss process whose cause has not been determined and which usually occurs in middle-aged women, lasting many months or even years. In the case of telogen alopecia, an interview with the patient is very important. Beside the hair loss type (focal or generalized), it should determine the beginning, period and concomitant symp- toms of the disease. It is vital to establish the manner and intensity of losing hair and the way it grows again as well as to collect information about hair care, past infections and an unbalanced diet (weight-loss, low-calorie and low-protein diets cause deficiencies of unsaturated fatty acids, B group vitamins, biotin and mineral components) and assess the patient's psychological condition. Approx. 30\% of patients suffering from telogen alopecia have a symptom of trichodynia, which involves pain, a burning sensation, itching or pricking within the scalp without any macroscopic disease lesions visible [1, 14, 15].

\section{Congenital and acquired structural disorders of the hair shaft}

Structural abnormalities of the hair shaft may exceptionally occur in congenital skin diseases. However, improper hair care and incorrectly performed hair beautifying procedures may contribute to acquired abnormalities of the hair shaft. The disorders are more frequent in blonde women. The affected hair is dry, brittle, matte, frail and thin. A spontaneous improvement is observed during pregnancy and after puberty. It is advised to avoid traumas. Internally applied vitamin preparations (mainly vitamin $\mathrm{H}$ ) and externally applied greasing preparations, conditioners or gels may cause a gradual improvement. Hair shaft changes involving increased brittleness include monilethrix ('beaded hair'), pseudomonilethrix, trichorrhexis nodosa, pili torti ('twisted hair'), trichothiodystrophy and trichorrhexis invaginata ('bamboo hair'). Hair shaft changes which do not involve increased brittleness include pili lanati, uncombable hair syndrome, pili annulati ('ringed hair'), ingrowing hairs, trichonodosis and trichoptilosis [1, 12, 16-19].

\section{Psychic disturbances concerning the hair}

Alopecia caused by traumatic factors is a group of diseases in which excessive hair loss is caused by mechanical factors. It includes hair loss caused by pulling or pressing and trichotillomania. Wearing a ponytail, using curlers and straightening cause hair loss. This process is usually reversible, but it may also lead to cicatrization. The only treatment method is to stop pulling the hair. Factors causing hair loss related to pressing include occipital area pressure in neonates lying down, children's habit of rubbing the head against a pillow, immobilization of chronically ill persons, head spins done by young people, traumas of neonates during labor and post-operative hair loss. Trichotillomania is a psychic disturbance involving persistent and uncontrollable compulsion to pull off one's own hair. The skin in shaved areas does not change. It occurs much more often in women and one third of patients is children (mainly girls). The compulsion to pull off one's own hair is sometimes accompanied by the compulsion to eat it, which is called trichophagia. The 
therapy includes psychoeducation, psychotherapy and taking antipsychotic drugs. Trichotemnomania consists in hair cutting or shaving, whereas trichodaganomania involves biting one's own hair as well as biting it off in various hair-covered areas of the body that can be reached with the mouth. Trichoteiromania means rubbing the hair and scratching the hair-covered skin, which leads to loss of or visible damage to the hair [1, 3-5, 12, 20-22].

The scalp is often the primary location of infectious lesions. These include scalp mycosis, caused by dermatophytes and most common among children. It usually manifests itself as erythematous and exfoliating lesions. The following clinical variants of scalp mycosis may occur: trichophytosis, trichophytosis profunda, favus and microsporosis. Scalp mycosis therapy depends on the clinical form of the mycotic infection and the type of pathogen that caused it. In most cases general therapy is applied (i.e. antimycotic drugs are used), while topical treatment is only supportive $[1,23,24]$. Pediculosis capitis is a parasitic disease caused by an ectoparasite - the head louse. It is epidemic and involves intense pruritus and secondary skin lesions [25]. The therapeutic process of pediculosis capitis consists in several elements: topical treatment involving mechanical removal of nits, general treatment, prophylaxis and monitoring the patients' surroundings [26, 27]. Folliculitis decalvans is another rare disease entity in this group; it is mainly observed in men and involves scalp hair loss and progressive cicatrization of the hair follicles. The therapy is a challenge because satisfactory improvement is often hard to achieve. The first-line therapy is antibiotics. Orally administered glycocorticosteroids, retinoids or sulphones are also used $[28,29]$. Perifollicular phlegmonous inflammation is a severe form of the profound inflammation of hair follicles which leads to their degradation. It has a chronic course and is typical of young men, especially black ones. The therapy is difficult. It is stressed that treatment should be systematic and several systemic preparations should be used simultaneously, which seems promising in the therapy of this complex disease entity [30, 31].

One should also briefly present diseases of inflammatory etiology with concomitant exfoliation and frequent pruritus. This group includes among others dandruff, seborrheic dermatitis of the scalp, psoriasis, atopic dermatitis, lichen planus, lupus erythematosus and circumscribed scleroma (the latter three disease entities are described in the section concerning alopecia cicatricans). Dandruff means exfoliation of the scalp, most commonly in the form of fine flakes with concomitant seborrhea of various intensity. This process is usually chronic and varies depending on the season. There are two basic dandruff types: ordinary dandruff and pityriasis steatoides (greasy dandruff). Asbestos-like dandruff is characterized by thick, silvery-white scales which are hard to eliminate. An incorrect name of this dandruff form - tinea - can sometimes be encountered, but it is known that mycotic etiology is excluded here. The therapy of scalp dandruff is first and foremost topical treatment based on shampoos, liquids and masks which exert a keratolytic, cytostatic and antimycotic action. The improvement is only transient in many cases and requires significant orderliness and patience of the treated person [1, 12, 32]. Seborrheic dermatitis is an inflammatory condition of the skin which has a chronic and persistent course. It involves typical exfoliation mainly on the scalp and other areas rich in sebaceous glands. Topical treatment with shampoos and liquids is the first element of the therapy which reduces exfoliation and inflammation. Similarly to dandruff therapy, one uses agents which exert a keratolytic, cytostatic and antimycotic action. Another important therapeutic component is phototherapy. Oral therapy includes retinoids, antibiotics, imidazole preparations and (sometimes) glycocorticosteroids. These are applied in the cases involving exceptionally intensified lesions or frequent recurrence of the disease. Antimycotic preparations are used especially often. Prophylaxis is very important here. Polish recommendations advise one to use ciclopiroxolamin in a shampoo once a week for several months or $200 \mathrm{mg} /$ day of itraconazole for 2 subsequent days of each month [1, 12, 32, 33].

Psoriasis is a chronic recurrent skin disease of an inflammatory-proliferative nature. It is characterized by typical papules and laminae covered by significant amounts of silvery-white scales. According to recommendations of the Polish Dermatological Society, therapy of scalp psoriasis involves first and foremost topical treatment. At the first therapeutic stage it is advisable to use preparations with a keratolytic action in order to remove excessive scales. The next group of substances is preparations with a reducing action. An alternative therapy applies a large group of vitamin D derivatives. Scalp psoriasis is treated using glycocorticosteroid preparations, retinoids and calcineurin inhibitors. They can be obtained as solutions, gels, shampoos and foams. If scalp psoriasis involves intensified lesions and a satisfactory improvement cannot be achieved, it is admissible to apply a classical general therapy (e.g. methotrexate, retinoids, cyclosporin A) [34, 35].

Atopic dermatitis is an inflammatory disease of a chronic and recurrent nature with concomitant pruritus; the patient's family history features cases of atopy. Atopic dermatitis of the scalp is more frequent in women living in cities (atopy in their parents is more common). It is recommended to treat this disease with calcineurin inhibitors, which are first applied externally twice a day and then twice a week (supportive treatment) so that they can reduce disease recurrence. Glycocorticosteroids as solutions or liquids can initially be applied once or twice a day and then an interrupted therapy alternating with neutral substances is recommended. In severe cases it is advised to apply phototherapy (PUVA or a UVB comb) three times a week for 6 weeks. In general therapy it is 
advisable to use azole antimycotic drugs or (sometimes) antihistaminic drugs. Appropriate scalp care is recommended in atopic dermatitis; it consists in moisturizing and avoiding irritating substances. Conditioning preparations of special significance are those that contain urea, ceramides, natural oils and topical analgesic agents. The scalp should be washed in water with the same temperature as that of the human body and without detergents. It is recommended to dry the hair and skin without rubbing and then apply neutral moisturizing-greasing preparations on the skin. In terms of care, it is important to use dermocosmetics with $\mathrm{pH} 5.5$ which do not contain potentially allergenic or irritating substances [36].

Alopecia cicatricans is a rare set of disturbances causing permanent and irreversible hair loss. Selection of a correct therapy for this disease depends first and foremost on the type of cells in the inflammatory infiltration observed in the histopathological examination of the skin specimen. If lymphocytic infiltrations dominate (lichen planopiralis, frontal fibrosing alopecia, pseudopelade of Brocq, discoid lupus erythematosus), it is recommended to apply a therapy based mainly on immunomodulating and/or immunosuppressive drugs. Alopecia with dominant neutrophil infiltrations (folliculitis decalvans) responds better to a therapy based on antibiotics and sulphones.

If no active inflammatory infiltrations are found in the skin specimen, there is no need to begin treatment because the alopecia process itself is no longer active and the disease is undergoing self-limitation.

Lichen planus is a non-infectious disease affecting both hair-covered and bare skin, nail plates and mucous membranes. It involves intense pruritus and typical papules. Initial treatment consists in applying glycocorticosteroids externally and intradermally; alternatively, one can use calcineurin inhibitors. Systemic treatment includes antimalarial drugs applied for at least 6 months and glycocorticosteroids for at least 3 months (the application is indicated only if the disease progresses quickly or the symptoms intensify). Cyclosporin A (CyA) is the immunosuppressive drug recommended; in a small number of patients, acitretin or isotretinoin is effective. Excimer laser phototherapy is effective only in the active (and especially in the initial) phase of the disease. A special variant of lichen planus is frontal fibrosing alopecia (FFA), which occurs first and foremost in postmenopausal women. Externally applied drugs include strong glycocorticosteroids and calcineurin inhibitors. Stopping the disease process and alleviating scalp ailments (e.g. pruritus) is a satisfactory result itself to many patients. As regards the general therapy, attempts are made to apply immunomodulating, immunosuppressive and anti-inflammatory drugs. It is recommended to use antimalarial drugs, isoniazid, sulphones, non-steroidal anti-inflammatory drugs, glycocorticosteroids (which demonstrate varying effectiveness), antibiotics (rifampi- cin, clindamycin), retinoids. Pseudopelade of Brocq, i.e. pseudo-alopecia areata (compared to "footprints in the snow") has not been unequivocally classified yet: it is thought to be either a primary scalp disease or the final stage of lupus erythematous or lichen planus (without clinical features of an inflammatory condition). It occurs first and foremost in 30 to 50-year-old dark-haired women. If the disease affects less than $10 \%$ of the head surface, glycocorticosteroids or calcineurin inhibitors are applied externally. However, if more than $10 \%$ of the head surface are affected and the disease progresses quickly, it is recommended to apply a general therapy with antimalarial drugs, isotretinoin or mycophenolate mofetil. One can also consider a bridging therapy with glycocorticosteroids for the first 2 months of applying an antimalarial drug, which allows for achieving an improvement before the first results of treatment with antimalarial drugs appear. Antimalarial drugs are effective only in 'etat pseudopelade' ('a pseudopeladic stage') in the course of discoid lupus erythematosus (DLE), while in primary idiopathic pseudopelade they are ineffective. Initial treatment of scalp DLE involves the use of strong glycocorticosteroids applied externally twice a day as an ointment or cream. This treatment can be supplemented with topical injections of triamcinolone administered intrafocally every 4-6 weeks. One can also apply calcineurin inhibitors externally. If no improvement is visible after 3 months, systemic treatment should be applied. Preferred drugs include antimalarials, immunosuppressive drugs, retinoids, acitretin, isotretinoin and mycophenolate mofetil. Folliculitis decalvans is a chronic disease and is difficult to treat. It affects the scalp as well as (rarely) eyebrows and beard. Since the most likely cause of this alopecia form is pathological bacterial biofilm, the treatment involves first and foremost antibiotics. The most often advisable ones are rifampicin with clindamycin for approx. 3 months. It is recommended to have two to three treatment sessions as this significantly prolongs remission and reduces the risk of recurrence. If clindamycin is not tolerated, one can consider the application of another antibiotic with rifampicin. The length of remission depends on the period of applying low antibiotic doses, which do not eliminate the bacteria altogether, but stop their growth for a long time. Antibiotics in ointments can be used externally and one can try to alleviate the pruritus with a steroid ointment. Other possible drugs include glycocorticosteroids (systemic application), retinoids and a recently introduced therapy with biological inhibitors of the tumor necrosis factor (TNF). In general, surgical treatment is preferred in the cases of alopecia cicatricans. This method is recommended for young patients whose cicatrix is stable and does not exceed $30 \%$ of the scalp surface. Recurrence is possible except the cases where the factor exerted only a one-time action (e.g. a trauma). The decision about when to consider a surgical procedure remains debatable. It is believed that this should happen after approx. 
2 years of full stability of the disease, during which it was not necessary to apply any kind of therapy maintaining the remission. If the disease process in the pseudopelade is stable, it is possible to conduct hair transplantation because no other therapeutic methods exist [1, 12, 37-46].

The main function of scalp hair is to beautify the person. It is very important to many people in the creation of their image, so alopecia may be a strong emotional experience. It can cause fear, depression, unfavorable judgments of one's own appearance and low general self-esteem, especially in women. Hair diseases are serious medical problems, so they should be treated by a dermatologist and endocrinological or gynaecological consultation should also be possible.

\section{Conflict of interest}

The authors declare no conflict of interest.

\section{References}

1. Brzezińska-Wcisło L, Wcisło-Dziadecka D, Bergler-Czop B, Lis-Święty A. Choroby włosów i skóry owłosionej. Brzezińska-Wcisło L (ed.). Termedia, Poznan 2015.

2. Chon SY, Champion RW, Geddes ER, Rashid RM. Chemotherapy-induced alopecia. J Am Acad Dermatol 2012; 67: 37-47.

3. Białynicki-Birula R, Migdał E. Łysienie wywołane przez chemioterapię przeciwnowotworową. Dermatol Klin 2006; 8: 108-13.

4. Latusek M, Brzezińska-Wcisło L. Polekowe zaburzenia struktury i wzrostu włosów. Dermatol Prakt 2012; 6: 12-8.

5. Piraccini BM, Iorizzo M, Rech G, Tosti A. Drug-induced hair disorders. Curr Drug Saf 2006; 1: 301-5.

6. Chave TA, Mortimer NJ, Hutchinson PE. Agranulocytosis and total scalp alopecia following acitretin. Br J Dermatol 2003; 148: 1063-4.

7. Apsner R, Hörl WH, Sunder-Plassmann G. Dalteparininduced alopecia in hemodialysis patients: reversal by regional citrate anticoagulation. Blood 2001; 97: 2914-5.

8. Trüeb RM. Diffuse hair loss. In: Hair growth and disorders. Blume-Peytavi U, Tosti A, Whiting DA, Trüeb R (eds.). Springer-Verlag, Berlin, Heidelberg 2008; 269.

9. Shapiro J. Hair loss in women. N Engl J Med 2007; 357: 162030.

10. Perger L, Bürgi U, Fattinger K. Pharmacotherapy of hyperthyreosis - adverse drug reactions. Ther Umsch 2011; 68: 303-8.

11. Asch PH, Caussade P, Marquart-Elbaz C, et al. Chloroquineinduced achromotrichia. An ultrastructural study. Ann Dermatol Venereol 1997; 124: 552-6.

12. Wolff H. Choroby włosów. In: Braun-Falco Dermatologia. WHC Burgdorf, G Plewig, HH Wolff, et al. (eds.). Czelej, Lublin 2010; 1053-82.

13. Trüeb RM. Chemotherapy-induced alopecia. Semin Cutan Med Surg 2009; 28: 11-4.

14. Sinclair R. Chronic telogen effluvium: a study of 5 patients over 7 years. J Am Acad Dermatol 2005; 52: 12-6.

15. Żak-Prelich M, Sysa-Jędrzejowska A. Łysienie rozlane kobiet - problem diagnostyczny i terapeutyczny. Świat Med 2001; 5: 39-43.

16. Brzezińska-Wcisło L, Lis-Święty A, Wcisło-Dziadecka D, et al. Wrodzone i nabyte zmiany struktury włosów. Post Dermatol Alergol 2007; 24: 282-9.
17. Cheng AS, Bayliss SJ. The genetics of hair shaft disorders. J Am Acad Dermatol 2008; 59: 1-22.

18. Itin PH, Fistarol SK. Hair shaft abnormalities-clues to diagnosis and treatment. Dermatology 2005; 211: 63-71.

19. Lester $L$, Venditti C. The prevalence of pili multigemini. Br J Dermatol 2007; 156: 1362-3.

20. Szepietowski J, Pacan P, Reich A, et al. Psychodermatologia. Akadamia Medyczna we Wrocławiu, Wrocław 2012.

21. Duke DC, Keeley ML, Geffken GR, Storch EA. Trichotillomania: a current review. Clin Psychol Rev 2010; 30: 181-93.

22. Szepietowski J, Salomon J, Pacan P, et al. Frequency and treatment of trichotillomania in Poland. Acta Derm Venereol 2009; 89: 267-70.

23. Miziołek B, Brzezińska-Wcisło L, Wcisło-Dziadecka D, et al. Trichological problems related to menopause. Post Nauk Med 2015; 3: 211-6.

24. Baran E. Mikologia - co nowego? Cornetis, Wrocław 2008.

25. Pinheiro AM, Lobato LA, Varella TC. Dermoscopy findings in tinea capitis: case report and literature review. An Bras Dermatol 2012; 87: 313-4.

26. Feldmeier H. Pediculosis capitis: new insights into epidemiology, diagnosis and treatment. Eur J Clin Microbiol Infect Dis 2012; 31: 2105-10.

27. Madke B, Khopkar U. Pediculosis capitis: an update. Indian J Dermatol Venereol Leprol 2012; 78: 429-38.

28. Jahns AC, Lundskog B, Nosek D, et al. Microbiology of folliculitis decalvans: a histological study of 37 patients. J Eur Acad Dermatol Venereol 2015; 29: 1025-6.

29. Otberg N, Kang H, Alzolibani AA, Shapiro J. Folliculitis decalvans. Dermatol Ther 2008; 21: 238-44.

30. Tsiskarishvili NV, Katsitadze AG, Tsiskarishvili T. Perifolliculitis capitis abscedens et suffodiens (case report). Georgian Med News 2012; 205: 19-23.

31. Jacobs F, Metzler G, Kubiak J, et al. New approach in combined therapy of perifolliculitis capitis abscedens et suffodiens. Acta Derm Venereol 2011; 91: 726-7.

32. Brzezińska-Wcisło L, Wcisło-Dziadecka D, Lis-Święty A, Trzmiel D. Łupież i łojotokowe zapalenie owłosionej skóry głowy - patogeneza, obraz kliniczny oraz aspekty terapeutyczne. Post Dermatol Alergol 2007; 24: 59-64.

33. Baran E, Szepietowski J, Maleszka R, et al. Łojotokowe zapalenie skóry i łupież: konsensus postępowania terapeutycznego. Wytyczne rekomendowane przez Polskie Towarzystwo Dermatologiczne. Derm Klin 2006; 8: 229-34.

34. Sandoval LF, Pierce A, Feldman SR. Systemic therapies for psoriasis: an evidence-based update. Am J Clin Dermatol 2014; 15: 165-80.

35. Szepietowski J, Adamski Z, Chodorowska G, et al. Leczenie łuszczycy - rekomendacje ekspertów Polskiego Towarzystwa Dermatologicznego. Część I: łuszczyca łagodna, łuszczyca wieku dziecięcego. Przegl Dermatol 2012; 99: 83-96.

36. Kaffenberger BH, Mathis J, Zirwas MJ. A retrospective descriptive study of oral azole antifungal agents in patients with patch test-negative head and neck predominant atopic dermatitis. J Am Acad Dermatol 2014; 71: 480-3.

37. Filbrandt R, Rufaut N, Jones L, Sinclair R. Primary cicatricial alopecia: diagnosis and treatment. CMAJ 2013; 185: 1579-85.

38. Shapiro J, Orberg N. Lichen planopilaris. UpToDate 2015.

39. Rácz E, Gho C, Moorman PW, et al. Treatment of frontal fibrosing alopecia and lichen planopilaris: a systematic review. J Eur Acad Dermatol Venereol 2013; 27: 1461-70.

40. Jain S. Pseudopelade of Brocq: a clinico-therapeutic challenge! Health Renaissance 2013; 11: 273-5. 
41. Vańó-Galván S, Molina-Ruiz AM, Fernández-Crehuet P, et al. Folliculitis decalvans: a multicentre review of 82 patients. J Eur Acad Dermatol Venereol 2015; 29: 1750-7.

42. Rongioletti F, Christana K. Cicatricial (scarring) alopecias: an overview of pathogenesis, classification, diagnosis, and treatment. Am J Clin Dermatol 2012; 13: 247-60.

43. Shapiro J. Cicatricial alopecias. Dermatol Ther 2008; 21: 211.

44. Tyagi V, Singh PK. A new approach to treating scarring alopecia by hair transplantation and topical minoxidil. Indian J Dermatol Venereol Leprol 2010; 76: 215.

45. Donovan JC, Shapiro RL, Shapiro P, et al. A review of scalp camouflaging agents and prostheses for individuals with hair loss. Dermatol Online J 2012; 18: 1.

46. Banka N, Bunagan MJ, Dubrule Y, Shapiro J. Wigs and hairpieces: evaluating dermatologic issues. Dermatol Ther 2012; 25: 260-6. 